\title{
79
}

\section{Ten years of information technology policy in Norwegian education}

\author{
Sindre Røsvik \\ Giske kommune \\ Øvre Nordstrand \\ Valderøy \\ Norway
}

\begin{abstract}
This paper highlights the Norwegian educational Information Technology (IT) policy over the last ten years with its main focus on primary and secondary school level. Recent curricular guidelines (1994/1997) do not give special priority to IT and treat IT within normal administrative routines. Still priority is given to and understanding advocated of the potential and importance of IT in education. This paper comments on this situation in the educational field.
\end{abstract}

Main conference themes: national policies

Educational areas: primary education, secondary education Study topics:

Secondary keywords: curriculum policies, government, management, politics 


\section{INTRODUCTION}

Educational policies in the world today are dominated by expansion and reform, by concerns for equality, balancing private resources and public responsibility, autonomy and accountability, centralization and decentralization, convergence and divergence in approaches to national development and educational reform [1]. Changes are caused both by external and internal educational demands and needs. In Norway educational expansion takes place both in the lower levels of primary education (6 year old children) and in upper secondary education (16 to 19 year olds) where students now have a right to three years of secondary education leading to further studies or a professional occupation. Also the capacity of higher education has been expanded. This growth expresses an increased understanding of the importance of education in modern societies. Economic stagnation and decline have been put forward as reasons for change. New technologies, particularly information technology, have contributed to an increasing unemployment on the one hand and new opportunities on the other hand.

For the last decade decentralization of political management has been a major trend. In the educational area this change has been discussed against the background of demands for national standards for schools where equal opportunities in education, independent of social class and geography, are considered to be basic. On the other hand local selfgovernment with the possibility of local adjustments to meet local needs is highly valued. Educational policies should strike a balance between both demands.

At the national level Parliament and Government, through the Ministry of Education, make sure that national aims and objectives of education are reached in every classroom. A policy for information technology in education is therefore also a national responsibility implemented by municipalities, counties and the Ministry of Education.

\section{COMPUTERS ON THE EDUCATIONAL AGENDA: TEN YEARS OF DEVELOPMENT}

"A small step for me, but a great leap for manhood." These were the famous words uttered by Neil Armstrong after his first step on the moon. Introduction of computers in education so far seems to be the opposite: a great leap for the individual, but a small step for education.

Around 1983 there was an urge for action. Information technology was introduced into all areas of working life as well as in everyday life. The personal computer was a reality and affordable. Among politicians and policy 
makers the quick development of the home market raised concerns about educational equity.

Until 1984 the use of computers in education was a matter of special interest only. Programming was a voluntary subject in schools dependent on human resources. With the introduction of the Personal Computer (PC) in the eighties there was a world-wide awakening to computers in education. Several countries developed national plans for the use of computers in education. Two examples: the Swedish Parliament decided that computer literacy should be developed over a three-year period from 1984/85 [2]. Australia established a national programme in 1984 [3].

\section{Milestones}

\section{The Plan of Action of 1984}

In 1984 a milestone was reached in Norway when Parliament approved White Paper No. 39 (1983/84), a programme for action to introduce computer technology into schools through experimental activity in selected areas and selected schools. A ministerial task force was established to organize and coordinate the programme with the clear purpose to prepare for the introduction of compulsory IT in Norwegian schools.

General introduction of IT in schools resorted under the Ministry of Education in cooperation with the regional school directors and National Advisory Councils, and was not within the mission of the task force. The work of this task force could rather be defined as an innovation programme preparing a reform or "a considered effort to improve practice related to given goals" [4].

Main element in the strategy outlined in White Paper 39 was a programme of action carried through by the task force. It was evaluated by an external agency (IMTEC) [5]:

- Project strategy approach with experimental activity in selected areas and schools. Selected areas: Special education and vocational training.

- Hardware: Specifying standards of graphics and operating systems.

- Software development defined as important.

- Teacher training and competence development: Training and expert networks.

The plan of action had both a top-down approach and a bottom-up strategy: the programme defined goals and aims nationally in White Paper 34 (83/84), but the schools by invitation defined their own projects, processes and goals.

One of the evaluation conclusions was that the most critical success factor was the schools' ability to master the trial process [5]. At the closing session 
of the IFIP working conference 'Exploring a new Partnership: Children, Teachers and Technology' more or less the same conclusion was reached: introduction of IT faces the same challenges as every other innovation project; in this respect there is nothing special about IT. The challenge is to handle teaching and learning strategies in an appropriate way.

\section{New Curriculum Guidelines}

The urge to implement IT in education was so strong that the compulsory introduction was started before any results from the programme of action were available and before information technology, in a broad sense, was made integral part of every subject in primary and lower secondary education. In 1985 a preliminary edition of new curricular guidelines appeared. In 1987 the final version was approved by Parliament, one year before the programme of action was fulfilled and final evaluation results were published. These guidelines announced the introduction of the information age and advocated a broad approach: introduction of IT to all students, integrated in all subjects as well as in methods of teaching and learning.

Implementing IT in the intermediate period 1988-1993

In the second phase several White Papers passed Parliament. In the period from 1988 to 1990 there were some organizational changes within the Ministry, but there was a continuing support for software development and other limited programmes like teleteaching.

A third phase was introduced by White Paper No. 14 (89-90) formulating a plan of action for information technology for schools and training for the period 1990-1993. An ambitious telecommunication programme called PEGASUS gave birth to a new one called WINIX. Great expectations were put upon WINIX, a sophisticated software concept handling telecommunication in an advanced way. This project turned out to be a stumbling stone almost costing the Minister of Education his seat. In spite of some successes the reputation of the educational IT projects was harmed by this particular programme.

It is against this background that White Paper No. 24 (93/94) must be understood which repeatedly emphazises that IT should be 'normalized' and that no 'special' money will be allocated to carry out this new programme of action. But can there be a programme when there is no extra money? And can there be 'normalization' when no personnel is designated to work with IT in education? 


\section{WHITE PAPER NO 24 (1993-94) ABOUT INFORMATION TECHNOLOGY IN EDUCATION.}

\section{Report from the Programme of Action 1990-1993}

This White Paper presented guidelines for IT in education for the years to come: The Ministry of Education's contribution, plans of action of trade, industry and public administration. Production of a White Paper is an internal affair of the Ministry, but different educational and technological groups were invited to contribute. On the 14th of January 1994 White Paper no. 24 (93/94) was released in print and via e-mail, immediately accessible to everyone.

\section{Content of White Paper 24 (1993/94)}

This 68 pages long White Paper provides educators with a lot of interesting and eye-opening reading, but a number of questions may be raised as well. The paper deals with the whole educational system with emphasis on primary and secondary education. It does not include computer science. The focus is on educational uses of information technology.

There is nothing sensational in the White Paper on how IT challenges educational policy (White Paper 24 (1993/94) p. 28-29): first of all students need to learn to use IT for the sake of future professional life, IT should be used as a tool for learning and finally IT is a subject in its own rights and an area of research.

Information technology is considered to be one of the most important tools for realizing efficiency, change, innovation and improvement of communication, and will have a growing role in the years to come. Unequal access to new information and communication technologies is reason for concern to which schools must respond. The state must play an active role; this is a question of democracy: the distribution of power and wealth.

IT in education is educationally motivated as well. A pedagogical basis is important on its own and will contribute to personal development of creativity, productivity and efficiency. The main questions for the educational system will be [6]: how can the educational system prepare the population for the information society appearing on the horizon? How can knowledge about new information and communication technologies contribute to newly formulated goals of educational policy?

Against this background educational policy has raised more questions, but given no answers. Take Cyberspace as an example, the linking of international information networks which creates new educational and professional possibilities like the global classroom. One project in Cyberspace is the KIDLINK-project initiated by a Norwegian journalist. Stressing equal possibilities teachers and politicians cannot be indifferent to the fact that most 
pupils do not have access to this virtual classroom. This development must be accessible for all students. Norwegian policy is to fulfil such goals through the National general curriculum guidelines for primary and secondary education.

\section{Success Factors}

The main factors listed in White Paper No. 24 (1993/94) are:

- development of pedagogical methods and ways of using IT;

- teacher training (preparatory and in-service);

- access to relevant software;

- access to hardware for teachers and students;

- dedicated personnel for system maintenance;

- possibilities for local, national and global communication.

IT has to be used in education on pedagogical terms. Competence in IT is a key factor as is access to relevant hardware and software. White Paper 24 emphazises that The Ministry of Education does not intend to establish national standards on either hardware or software. Ministerial bodies and partners will coordinate purchase of software, licenses, etc. and facilitate access to INTERNET.

\section{Aims, Ministerial Management and Organization}

Work on IT in education must follow the management model of The Royal Ministry of Church and Education, that is: normalization of IT in education with no extra funding and no allocated people responsible for IT at any level. Of course schools themselves may give priority to IT. The national level will develop plans and guidelines, inform and advice. Special attention may be paid to IT in education in this respect, but it seems that the Ministry relies on institutions, universities and municipalities to fulfil their responsibilities. But what if one or several municipalities fail, burdened with other local tasks such as care of the elderly? What if one or several teacher colleges are disloyal to the orders from the Ministry? A national plan of action must consider questions like these. To follow up on the situation in the schools the Ministry has developed a system of information gathering and may also perform special investigations.

Normal procedures of management must be the basis in every educational matter and any plan of action. Responsibility must be distributed to different levels, but there must be a system of support and development to spread information and link different specialists, schools and projects together facilitating international cooperation and development. With no extra money this has to be financed through the regular budgets. 


\section{Curriculum Guidelines of 1994 and 1997}

In 1994 there was a major reform of upper secondary education. IT is certainly given a substantial new role in this curriculum, integrated in subjects. To avoid immediate demands for increased resources for implementing the curriculum including IT a five years delay of fulfilment was explicitly accepted.

New curriculum guidelines are expected to be very specific on integration of IT in subjects and use of IT as a tool for learning. IT will be an obligatory part of the curriculum of both primary and secondary education. Norway now has common general guidelines for education of children from 6 to 18 years and a link between the common general guidelines and the subject curricula. Overall methods and attitudes to be used are described and should be followed, but there is very little mention of IT.

\section{CONCLUSIONS AND FUTURE PROGRAMME}

The Ministry seems open to ideas and proposals from professionals and others who want to contribute to a national plan of action. The results still remain to be seen.

The main keyword in White Paper No 24 (93/94) is normalization, with no special ministerial task force and with no extra IT resources. Sweden and Denmark have used hundreds of billions for these purposes. In Norway there will be (almost) no special software or hardware development conducted by the Ministry of Education. There is an understanding of the role and importance of IT in society and education. The will to be active on a national level is still considerable, but has to materialize in a plan of action and in new curriculum guidelines.

Questions which have to be answered soon, are:

- What is normal allocation for IT in education in a modern society, like Norway?

- Is it affordable not to use really big money in this field in the years to come?

- What about development and innovation if this is not done?

- Is it likely that municipalities will and are able to finance such development programmes?

- Will there be new initiatives for innovation and development or support for existing IT, and network building in this area in and outside of formal institutions?

- Finally: what will be done about the educational cornerstones, teacher education colleges and university programmes, when it comes to IT? 
Very strong efforts will have to be made to bring new attitudes and knowledge to a new generation of teachers. Successful implementation of IT in teacher education colleges is a necessity for a lasting and overall educational change in the service of future education.

\section{REFERENCES}

1. Arnbove, Altbach and Kelly (eds.) (1992) Emergent Issues in Education. Comparative Perspectives. New York.

2. Makrakis and Vasilios (1988) Computers in School Education: The Cases of Sweden and Greece. Institute of International Education, University of Stockholm, Täby.

3. Commonwealth Schools Commission (1984) Teaching, Learning and Computers: 1984 Information Kit. Canberra 1983.

4. Dalin, Per (1986) Skoleutvikling. Oslo.

5. Dalin, Stranden et al. (1989) Report No. 15: Goals and Results. Final report on the experimental work during the Program of Action. Oslo.

6. Ministry of Church and Education (1994) St. meld. $n r .24$ (1993/94) Om informasjonsteknologi i utdanningen. Rapport fra handlingsprogrammet 199093 og strategi for videre arbeid, Oslo 1994. 